\title{
The Sustainable Design Rules of Landscape
}

\author{
Khawla Kareem Kawther ${ }^{1, a}{ }^{*}$ and Rasha Hussien Hassan ${ }^{2, \text { b }}$ \\ ${ }^{1}$ Department of Civil Engineering, University of Technology, Baghdad, Iraq. \\ ${ }^{2}$ University of Baghdad, Baghdad, Iraq. \\ a40232@uotechnology.edu.iq, ${ }^{\text {brasha.h.h@uobaghdad.edu.iq. }}$
}

\begin{abstract}
After the global developments that occurred, the most important of which is the spread of the Covid 19 pandemic, it was imperative to pay attention to outdoor spaces to preserve public health. There are important of studying the relationships between sustainable landscape design, the people, and the urban environment. The research problem revolves around a commitment to sustainable landscape design rules, which included variables in the sustainable natural space environment: environment, economy, justice, beauty, experience, and ethics. The research hypothesis is that there must be a system for the variables of sustainable spaces that determine relationships, opportunities, contradictions, and system parameters about people's health and safety, environmental services, biodiversity, and resource management. To achieve the above goals must be studied; compatibility with systems, the positive effects of globalization, the appropriate scale, and the interactive - behavioral, meaningful landscapes, the distinctive paradigm, using the alternative landscape and regenerated landscapes.
\end{abstract}

Keywords: Sustainable design; rules; regenerated; alternative; landscapes; scale; and COVID 19.

\section{Introduction}

The designed landscape is a territory of land altered by individuals for aesthetic impact principally. This definition includes the natural spaces in which they are used, management, preservation, restoration by people in an environment and has the importance of increasing the natural capital and preserving the ecosystem, as well as preserving the cultural features of the urban population $[1,2]$. People have a negative or positive influence through the presence of management and control, for example, as the people have freedom of choice [3], whereas $\mathrm{Wu}$ in 2008 suggested that the activities of people can be reformulated in a new way by landscape architects to reach sustainable natural spaces [4]. One of the great challenges will be how we design sustainable landscape by integrating economic and environmental aspects, justice, ethical performance, and aesthetic experience in a civilized world through the overall relationships between sustainable external spaces, how people communicate with nature, and the problems involved.

Musacchio [5] suggested an approach and that provides the flexibility and capacity necessary for the transition to sustainable landscape designs. The problems of transitional sustainability depend on and revolve around multiple scales, and that the science of sustainability and the research of the landscape and its applications can be integrated. The researcher also created a vocabulary for sustainable landscape design: environment, economics, justice, aesthetics, experience, and ethics, and there is the conceptual system around these vocabularies of sustainability, which are interconnectedness, opportunities, contradictions, and determinants [5]. Through previous studies emphasizes for integration of the design with sustainable science as a solution to direct projects and activities around comprehensive relationships between the sustainability of landscape by studying the effect on people's health, human impact on the environment, and versa to achieve justice.

\section{Theoretical framework}

A Sustainable landscape is a new concept of designing parks or outdoor spaces in an urban environment that considers environmental sustainability. It includes the design, construction, and management of residential and commercial parks surrounding the various types of buildings and various scales [6]. It is presented about the vocabulary of the sustainability of external spaces for the design of 
external spaces and their main characteristics. The Vocabulary of the Sustainability of the landscape is the system that provides the conceptual structure

Compatibility with systems. It must recreate the interactions between people and nature by increase interactions of nature and culture if the relationship has become imbalanced; or that people have become the global force in reshaping the landscape that lead to environmental collapse, as well as the increasing urbanization leads to changing perception, increasing sensation, flexible design and changing perceptions to compatibility with systems and it must confirm benefits of urban conditions.

Effects of Globalization. The global scale needs to understand and how it affects outdoor spaces design. Studies confirm the linkage of land use with the regional environment, linked to the global scale. They also emphasize the need to know the changes that have occurred on all of the lands to make decisions. In addition, the design of local spaces must be adapted to global phenomena [5]. As is the case of the emergence of COVID 19, novelties in the environment affected the life of all humanity.

The Appropriate Scale. It is agreed in the science of sustainability that the best achievements in the research and practice of natural spaces that work on studying the complex spatial problems are those that have been achieved at the regional scale that connects to the global and the local scale. It an association of the distinct characteristics between the natural spaces, the regional identity, and the type of people in the settlement. The main challenge in moving to sustainable outdoor spaces is how to create communication between people with nature as a cohesive and coordinated unit that leads to more robust and scientific sustainable plans and policies, persuading them to move away from city centers where the overcrowded structure [7].

Interactive-Behavioral. Interactional space is inspired by interactional territory, which refers to suitable areas temporarily controlled by a group of interacting individuals [8]. External space researchers focused on using natural spaces and the gradient between urban areas down to rural, which raised serious concerns for external space researchers about the expansion of urban areas, which negatively affects biodiversity, which is an important aspect of differentiation in any area is core experiences in the nature local folk [9]. Nevertheless, people value the proximity to nature and greenery if it is near the house or work site, viewing or doing exercises. Proximity to nature and green helps reduce stress, improve attention, and give a better sense of the people who live in the urban and rural areas.

Meaningful Landscapes. Many different cultures recognize distinct natural spaces such as forests as a metaphor or symbol of their cultural identity. People are intimately acquainted with a sense of the natural space of a place. Devastation or negative changes can affect the inhabitants psychologically, prosperity, and society's identity and image $[10,11]$.

Distinctive Paradigm. It will find new species and reinterpret cultural concepts of people health and safety, multi-functionality, and ecosystem services. It is practical relationships that can be applied to outdoor spaces designed to help redefine and integrate the relationship between the people and nature in urban areas, practical relations such as the environment of reconciliation. Another called it the design of the democratic environment, or the overall people environment [12]. The challenge is to understand how to use the sustainability factors to find distinct places for humans that preserve biodiversity and cultural diversity that reduce stress and mental fatigue and improve people's interaction with nature. Landscape in urban areas is the center of this process and the most important one, and that by creating open areas within the densely populated urban blocks [13]. 
Alternative Landscape. It needs a new perspective on how distinct character can redefine people's expectations of nature, multi-purpose function, and ecosystem services and aesthetics. The rules require us to explore what is called an alternative landscape. It is a kind of designed landscape that appeared on a large scale by interpreting man's relationship with nature in the dual system. Here are some examples of alternative landscape:

- Community projects such as small parks, public gardens, and environmental revival projects see (Figure 1).

- Infrastructure projects and parks for landscaping on a large scale, see (Figure 2).

- Low-impact generic designs such as California village residences, see (Figure 3).

- Wildlife colonies of less charming and aesthetic species such as amphibians and some insects.

- The process of designing river streams and open streams that collect rainwater and take place inside the city, see (Figure 4).

- Vegetation integrated with building projects such as garden roofs and green vertical walls, as shown in Figure 5.

- Special designs from natural sources such as forest farms and bioenergy districts.

Alternative external spaces are directing people to peculiar types that they are not accustomed to, but with time, they turn into familiar things, and from a visual perspective, external spaces can appear as a natural, developing or architectural landscape. Meaning that it is not a requirement to be natural to achieve the rules of sustainable landscapes [14].
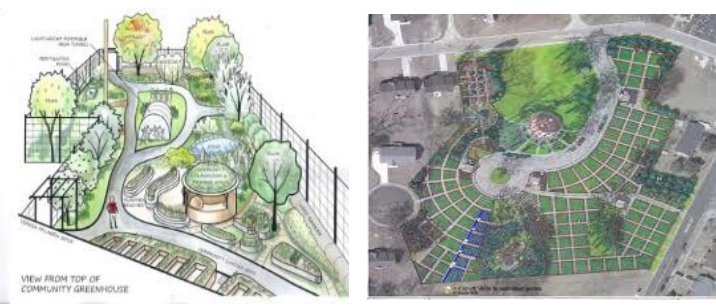

Figure 1. Scroo's gardens in residential complexes (small scale).
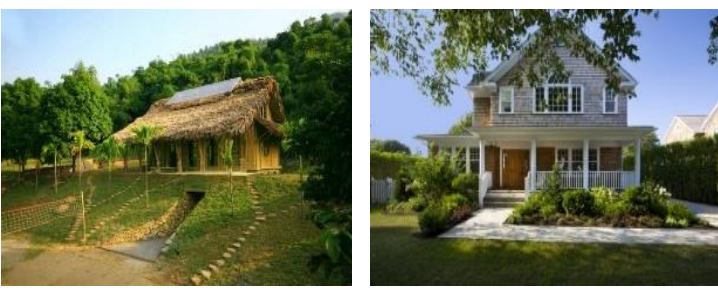

Figure 3.Village house garden village.

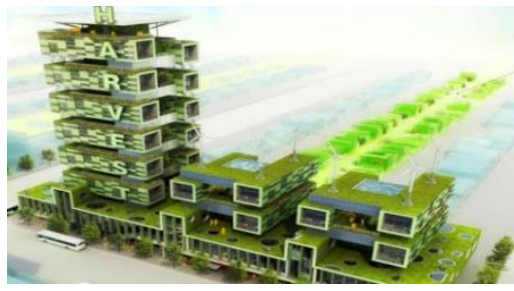

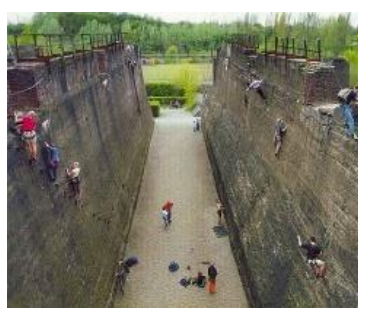

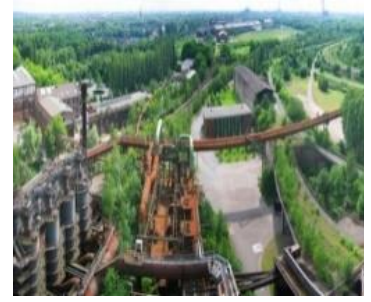

Figure 2. Large Scale Projects DuisburgNord Landscape Park in German.
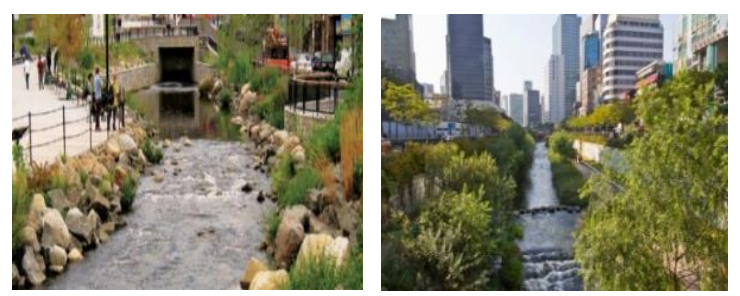

Figure 4. Rainwater collection tables.

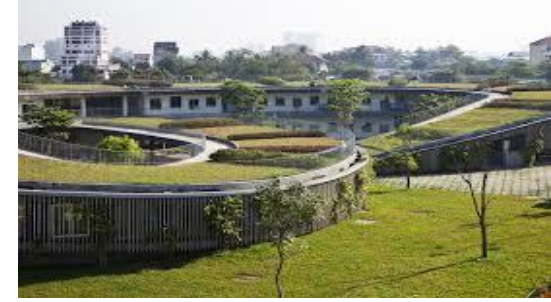

Figure 5. Green walls and ceilings.

One of the potential outcomes the emergence of sustainability professionals who can create new types of landscapes that may imprint people's lives, security, and ecosystem services with a completely new character, such as developments in bio-energy, modern housing paradigm, industrial waves, etc., which could change our perceptions about what nature and innovation might inspire us. New types about 
what we like and hate from vital paradigm, what we like or hate from technologies, in addition to what these terms generate in terms of acceptance or rejection by society or the way of dealing with them by scientists, students of science, and specialists in addition to citizens [15].

Regenerated landscapes. Preservation in landscape spaces represents a model for the coexistence of people and other living creatures in the environment and the exchange of assistance. The science of sustainability has proven the correlation of peripheral problems with the natural system and how these problems result from People's actions. It also confirmed that a shift towards sustainability can transform People's actions to slow down, fix and reverse the negative results of these actions into positive results follow are based on the principle of balance between the environment, economy, and justice [16]. The rules of sustainable landscape spaces suggest that any recipe for a shift towards sustainability needs to move further than it should be because of the link between the environment, the economy, and justice, on the one hand, experience, aesthetics, and ethics, on the other hand, is highly required for any recipe for change towards sustainability. Nevertheless, the People type has certain cognitive limits. To understand abbreviated terms such as the transition towards sustainability or a sustainable landscape. The contributed to the general knowledge of sustainable outdoor spaces that helps us and nature to coexist. It appears that the needs future methods based on maintaining a balance between:

- Rehabilitation of the previous environmental jobs and gatherings.

- Preserving natural conditions through correct environmental behavior [17].

\section{Case Studies}

A number of projects from different parts of the world have been selected for landscape spaces to determine the percentage of application of indicators.

The Garden Landschaftspark. Landschaftspark is a recreational area situated in Duisburg Nord, Germany. It was planned in 1991 by Peter Latz, with the expectation that it works to recuperate and comprehend the modern past instead of attempting to dismiss it. The recreation center intently connects itself with the site's past utilization: a coal and steel creation plant (deserted in 1985, leaving the region fundamentally dirtied) and the rural land it had been preceding the mid-nineteenth century. Origination and creation: "In 1991 a co-employable simultaneous arranging method with five global arranging groups was held to plan the recreation center. The plan was huge, as it endeavored to safeguard however much of the current site as could reasonably be expected. In contrast to his rivals, Latz perceived the estimation of the site's present condition. He permitted the contaminated soils to stay set up and be remediated through phytoremediation and sequestered soils with high harmfulness in the current shelters. He also discovered new uses for many old constructions and transformed the previous sewage waterway into a strategy for purifying the site [18].

Design: "The recreation center is partitioned into various territories, whose lines were deliberately evolved by taking a gander at existing conditions, (for example, how existing streets and railroads had separated the site, what kinds of plants had started to fill in every territory, and so on) This piecemeal example was then woven together by a progression of walkways and streams, which were set by the old railroad and sewer systems. While each piece holds its character, it likewise makes a discourse with the site encompassing it. Inside the fundamental complex, Latz underscored explicit automatic components: the solid dugouts make space for a progression of personal nurseries, old fuel tanks have become pools for scuba jumpers, rock climbers utilize solid dividers, and quite possibly the most focal spots of the production line, the center of the previous steel plant, has been made into the piazza. Every one of these spaces utilizes components to take into consideration a particular perusing of time. 
The aim of reviving the region, in general, is to preserve the region as a legacy that expresses the pinnacle of development that Europe reached after the Industrial Revolution while trying to make the most of it as possible after it became an abandoned area, so the designers tried to give it a contemporary spirit by adding much entertainment and cultural activities And sports and many activities to make it one of the most important places that people visit for hiking and practicing various activities. The authors notice through the pictures shown how the open and closed spaces, which include the old gables, were used in various ways and in an innovative way by the designers, so they took advantage of:

- Places for gathering, outside, and recreation.

- Places to play various types of sports such as climbing, swimming, skiing, and circus.

- Places of gathering and cultural events have been allocated, such as performing some musical performances (see Figure 6.
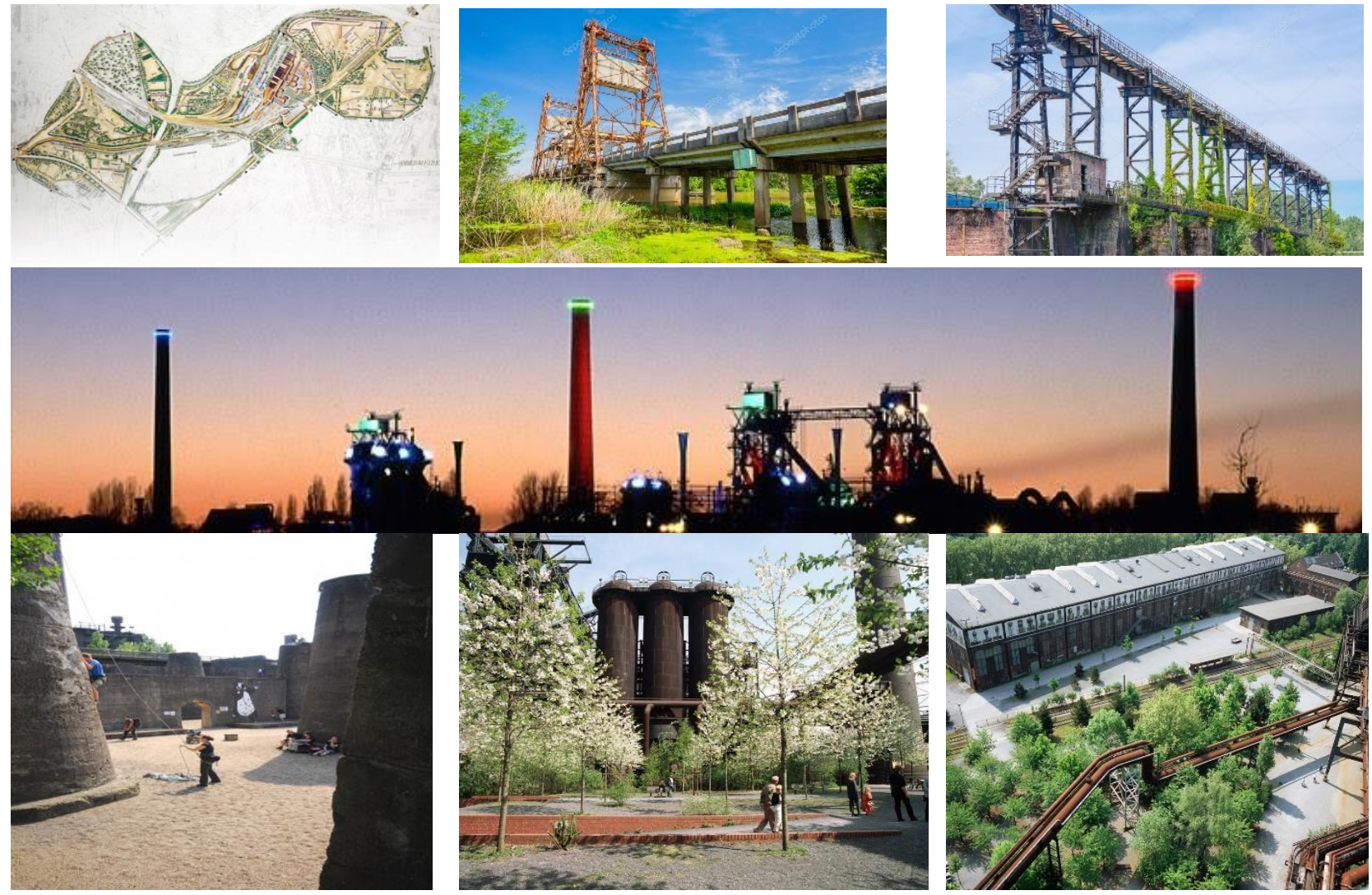

Figure 6. Showing the giant mechanisms and facilities at the site before the project. [19,20].

Gateway National Park. The park area extends $107.6747088 \mathrm{~km}^{2}$ of land of the New York and New Jersey harbor and coast. It is one of the most essential Park as a Public Park System in the United States. It was set up to support both common and metropolitan ecologies while giving sporting freedoms to districts' inhabitants. The recreation center is a vital asylum for the transient, it has been observed more than 330 bird in the sky, and it contains a variety of estuarine natural life territories. At the same time, Gateway is home to public seashores, memorable United States military strongholds, navigational offices, NY City's first metropolitan air terminal, and provincial infrastructural systems. The competition had goals taken into consideration, like, create an iconic landmark for the universal brand, the Gateway Arch, stimulate expanded imperativeness in the St. Louis area, honoring the components of the distinctive features of a National Historic Landmark. It embraces the Mississippi River and East Bank of Illinois as an indispensable piece of the public park. Develop a supportable future for the Jefferson National Expansion Memorial. Enhance the people encounter and establish an inviting and open climate [21]. 

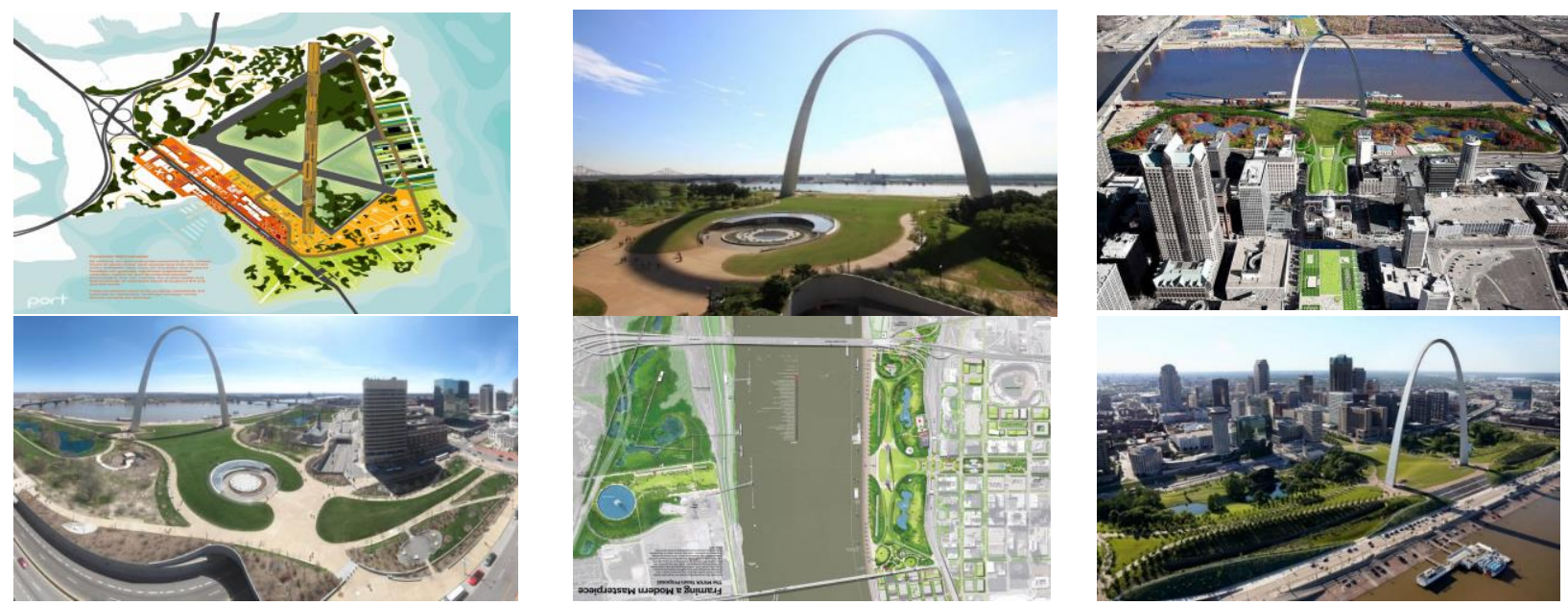

Figure 7. A Public Design Competition for Gateway National Park [22].

21st Century Waterfront Park Chattanooga, Tennessee. The master plan and design recover the first establishing of Chattanooga and weave this set of experiences all through the park" [23]. $0.522044 \mathrm{~km}^{2}$ of the land of advancement along both the north and south shores of the Tennessee River renew the openair insight. Parks, open space, fountains, and bridges animate the shores at evening time to expand new lighting. Sculptural lighting structures complement hubs and dissemination ways and give an improved feeling of the spot. Design Team: Robert Osten, Keith Yancey, it was completed in 2006 [24]. The design defines a privileged place character and makes a striking the waterfront for Chattanooga's entirety, and historical characteristics made the city remarkable. The recreation center's plan relinks the riverfront of city to its consolidating foundation and craftsmanship exhibition expansions, making the city's objective of "living, working, playing and learning at the waterway. The recreation center is essential to control the flooding for the waterway and security for the planning cycle, including broad local area commitment and broad coordination and survey with various offices, especially the US Army Corps of designers. Opportune endorsements were fundamental for the venture plan, and the dynamic interest with inspecting offices all through the plan interaction made this conceivable, see Figure 7 [25, 26].
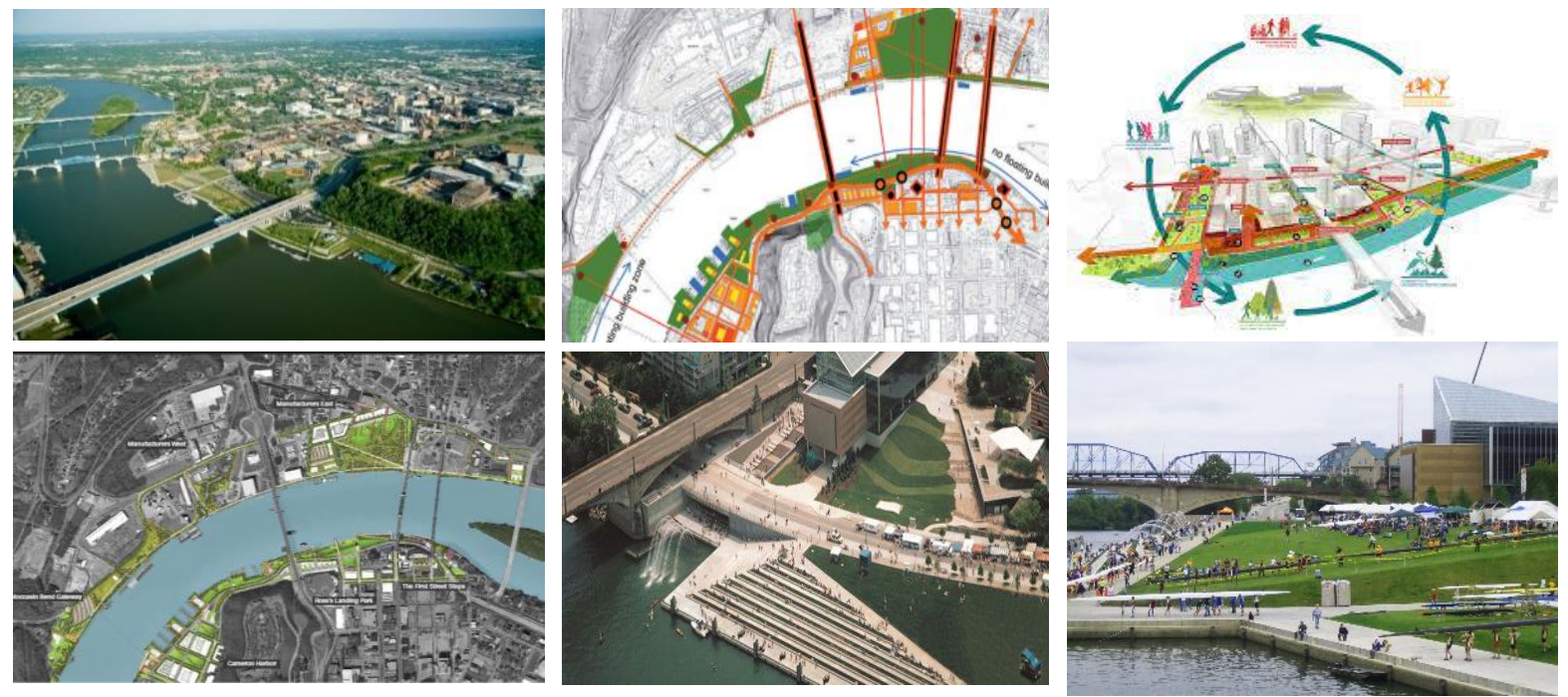

Figure 8. 21st Century Waterfront Park Chattanooga, Tennessee [25, 26].

Elizabeth Caruthers Park Portland, Oregon. Located in a newly developed Portland district on the Willamette River, the Park is $8093.71 \mathrm{~m}^{2}$ of urban land that active to nearby occupants, blossoming organizations, and the close by Oregon Health and Sciences University community [27]. The park's name is for a woman who was one of the first lives in this city [28]. It is named A Green Jewel, and its Mix used parks in the high-density residential quarter. The community achieves health objectives and all ages of people get more active in nature, helping reduce obesity...etc. It should urge more individuals to live 
nearer together to limit their resource use. The disadvantage to this urban density is individuals do not have a place to get out into nature; they need openings for amusement. In compact urban environments, parks and open spaces assist individuals with making an equilibrium. Parks empower individuals to have a solid way of life while appreciating the advantages of density: simple admittance to transportation systems and conveniences. The new community is encircled by high-rises housing, a big clinical center, and various dynamic building locales. It was once quite possibly the most mechanical locales in Portland. This was the boat-building exercises site that returned to the Liberty boats, see Figure 8 [29].
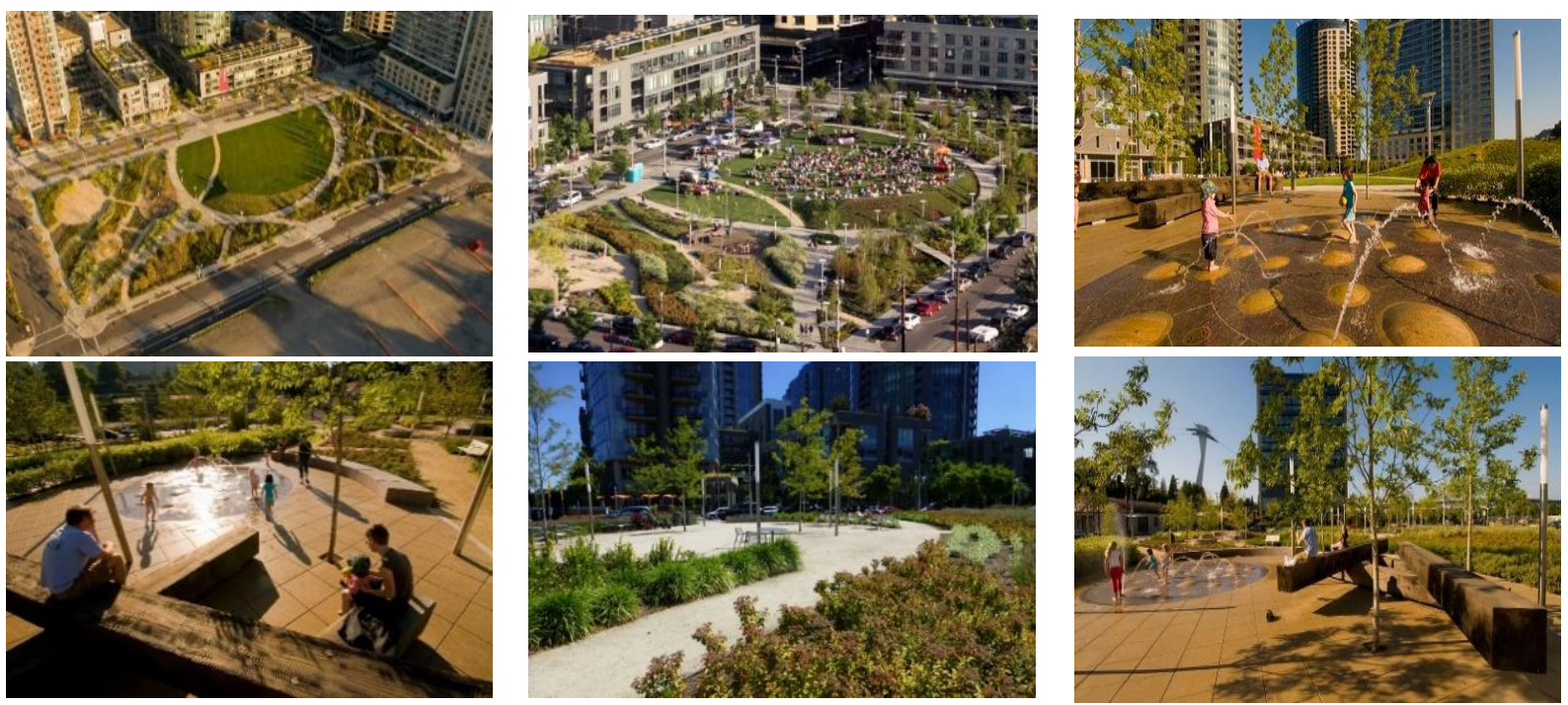

Figure 8. Elizabeth Caruthers Park Portland, Oregon [30,31].

Ribbon Park, Tianjin, China. It is a $0.323749 \mathrm{~km}^{2}$ Park along the Haihe River of Tianjin - the city of Tanggu. It has been planned with the rainwater infrastructure incorporated into the landscape to amplify its capacity while finding the aesthetic views. The rainwater practices executed into the design include marshland swales, exposed gravel channels, slot drains, rain gardens, and more. These practices aid in controlling rainwater runoff flows, decreasing erosion, and recover water quality. Besides providing the conveyance of rainwater through the park, selected portions of the park are designed to direct rainwater runoff into grade rainwater storage systems that will provide a renewable source of water for non-potable reuse [32]. The design achieves the balance by a simple structure of east/west striations that organize the park's sequence of spaces and straddle the active central promenade. This strong but simple design creates a landscape structure that belies the multiplicity of activities that include a pond for model boats that converts to ice skating in the winter, interactive fountains and art, Lifelike gardens flexible use lawns for play, see Figure 9 [33,34].
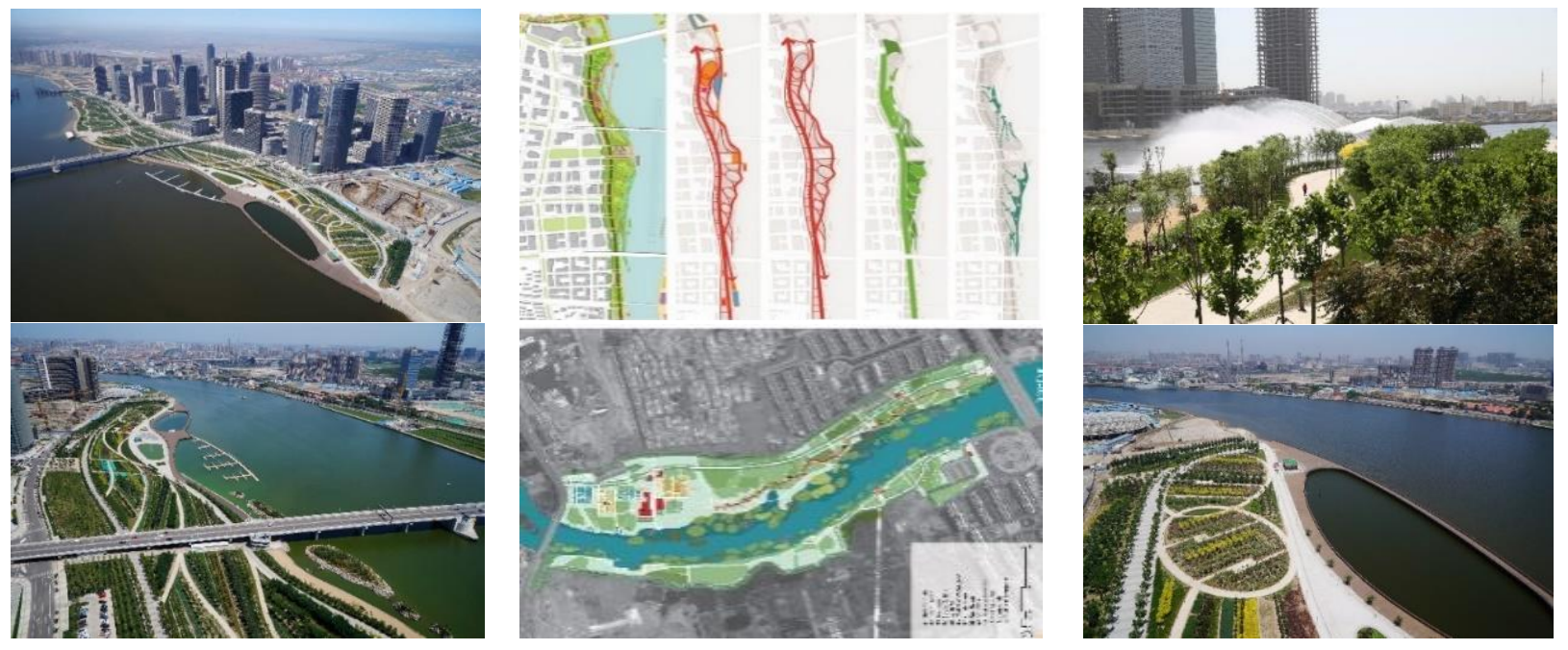

Figure 9. Ribbon Park, Tianjin, China [33,34]. 
Through the analysis of selected projects to reach the following results:

Table 1. The main characteristics and how well is achieved in the projects.

\begin{tabular}{|c|c|c|c|c|c|}
\hline \multirow[b]{2}{*}{ The main characteristics of park } & \multicolumn{5}{|c|}{ Projects } \\
\hline & $\begin{array}{l}\text { Landschaft } \\
\text { Garden } 1991\end{array}$ & $\begin{array}{c}\text { Gateway } \\
\text { National } \\
2007\end{array}$ & $\begin{array}{c}\text { Waterfront } \\
\text { Chattanooga } \\
2006\end{array}$ & $\begin{array}{c}\text { Elizabeth } \\
\text { Caruthers } \\
\text { Portland 2010 }\end{array}$ & $\begin{array}{l}\text { Ribbon } \\
\text { Tianjin }\end{array}$ \\
\hline Compatibility with systems & \#\#\#\# & $\#$ & \#\#\# & \#\#\#\# & \#\# \\
\hline Effects of globalization & \#\#\#\# & \#\#\# & \#\#\# & $\#$ & \#\#\#\# \\
\hline appropriate scale & \#\# & \#\#\#\# & \#\#\#\# & $\#$ & \#\#\#\# \\
\hline Interactive - behavioral & \#\#\#\# & \# & \# & \#\#\#\# & \#\# \\
\hline Meaningful Landscapes & \#\# & \#\# & \#\#\#\# & \#\#\# & \#\# \\
\hline Distinctive Paradigm & \#\#\#\# & \#\# & \#\#\# & \# & \#\#\# \\
\hline Alternative Landscape & \#\# & \#\#\#\# & \#\#\#\# & \#\# & \#\#\#\# \\
\hline Regenerated landscapes & \#\#\#\# & \#\#\#\# & \#\#\#\# & \#\#\#\# & \#\#\#\# \\
\hline
\end{tabular}

\section{Findings and Recommendations}

The proposed model for the sustainable transformation of the Rules for Sustainable landscape spaces represents a step towards understanding the complex role that external space design plays in sustaining people and ecosystem services. The challenge now is defining the aesthetics of sustainable external spaces based on accurate research of the rules and analyzing the lessons learned from experience. Sustainable external spaces do not depend only on a situation or a static geographic and temporal situation or something acquired through practice, because in reality, it embodied results of the multifunctional state that gives ecosystem services with flexibility and habituation. Here, questions arise, what are the possibilities for producing sustainable outdoor spaces in response to oceanic changes globally, regionally, and locally. The challenge is to respond strongly to the best knowledge and capabilities to achieve livable places that achieve well-being and health and resist the diseases that came with development. Achieving the Rules of Sustainable Landscape by Achieving the criteria: social identity in open spaces as Compatibility community with systems, the positive effects of globalization, the appropriate scale, and the interactive - behavioral, meaningful landscapes, the distinctive paradigm, through using the alternative landscape, and regenerated landscapes. There is a set of proposed arrangements:

- Creating open, healthy, and livable places near residential complexes.

- Reduction of stormwater runoff using downpour gardens, green rooftops, and dividers.

- Reduction of water use in scenes through the plan of water-wise nursery strategies (some of the time known as xeriscaping).

- Bio-separating of squanders through built wetlands.

- Irrigation utilizing water from showers and sinks, known as dim water.

- Good management procedures for bug control.

- Creating and upgrading untamed life natural surroundings in metropolitan conditions.

- Energy-productive nursery plan as the appropriate situation and choice of overhanging trees and formation of windbreaks.

- Permeable clearing materials to decrease stormwater and permit downpour water to invade into the ground and recharge groundwater instead of the surface water.

- Use of economically gathered, composite wood items for nursery utilizes, just as utilization of plastic timber.

- Materials recycling, like glass, elastic, to make scene items like clearing stones, mulch ...etc.

- Soil the executive's methods, including treating the soil kitchen and yard squander, to keep up and improve solid soil.

- Reception of environmentally friendly power, including sunlight-based, fueled lighting.

- Development of yard options, for example, xeriscaping, botanical yards, and knolls. 


\section{References}

[1] Musacchio, L. R. 2009. Pattern: Process metaphors for metropolitan landscapes. J. Ecology of Cities and Towns: A Comparative Approach, Cambridge University Press. pp. 484-502. https://doi.org/10.1017/CBO9780511609763.029

[2] Musacchio, L. R. 2008. Metropolitan landscape ecology: using translational research to increase sustainability, resilience, and regeneration, J. Landscape 27(1), pp.1-8. DOI: 10.3368/lj.27.1.1

[3] Alberti, M., Marzluff, J.M., Shulenberger, E., Bradley, G., Ryan, C., Zumbrunnen, C. 2003. Integrating Humans into Ecology: Opportunities and Challenges for Studying Urban Ecosystems. J. Bioscience, 53, pp.1169-1179. https://doi.org/10.1641/0006-3568 053[1169:IHIEOA]2.0.CO;2

[4] Jianguo, W. u. 2008. Making the Case for Landscape Ecology An Effective Approach to Urban Sustainability, J. Landscape 27, (1). https://www.jstor.org/stable/43323803

[5] Musacchio, L. R. 2009. The scientific basis for the design of landscape sustainability: A conceptual framework for translational landscape research and practice of designed landscapes and the sixes of landscape sustainability, Landscape Ecology, 24(8), pp.993-1013. https://doi.org/10.1007/s10980009-9396-y

[6] M. Loehrlein, 2020. Sustainable Landscaping: Principles and Practices. 2nd ed., CRC Press, U St. https://doi.org/10.1201/9780429285974

[7] Saha, D., Paterson, R.G. 2008. Local government efforts to promote the Three Es of sustainable development: survey in medium to large cities in the United States. J. Plan Educ Res 28 pp. 21-37. https://doi.org/10.1177/0739456X08321803

[8] Shojai, A. Fattahi, K. 2021. Left open spaces — light shafts in Iran and side setbacks in Japan: a sociospatial approach to study awareness in open spaces in urban residential blocks. J. City Territ Archit 8, 2. https://doi.org/10.1186/s40410-021-00131-4

[9] Turner, W.R., Nakamura, T., Dinetti, M. 2004. Global urbanization and the separation of humans from nature. J. Bioscience 54 pp.585-590.

[10] Horowitz, P., Lindsay, M., O’Connor M., and Biodiversity, M. 2001. Endemism sense of place, and public health: inter-relationships for Australian inland aquatic systems. J. Ecosyst Health 7, pp.253-265.

[11] Rafat1, R., Mirhadi, S. 2017. Designing Meaningful Landscapes through Systematic Discovery of Character of Place, J. Civil Engineering and Architecture 5(3), pp.89-93.

DOI: 10.13189/cea.2017.050303

[12] Kawther, K.K., Hussien, R. Sabih, N. 2020. The pavements by precast concrete flags IOP Conf. Ser.: Mater. Sci. Eng., 737 012209. doi:10.1088/1757-899X/737/1/012209

[13] Brown, F.E., Neary, S.J., and Symes, M.S. 1994. Public spaces and public life in urban areas, in: S.J. Neary, F.E. Brown, and M.S. Symes, (Eds.). The Urban Experience: A People-Environment Perspective, 1st ed., Routledge. https://doi.org/10.4324/9780203222270

[14] Meyer, E.K., 2012. Sustaining beauty. The performance of appearance: a manifesto in three parts. J. Landscape Arch Spring. https://doi.org/10.1080/18626033.2008.9723392

[15] Thayer, R.L. 1994. Gray world, green heart: technology, nature, and the sustainable landscape. Wiley, New York.

[16] Kates, R.W., Parris, T.M. 2003. Long-term trends and a sustainability transition. J. Proceedings of the National Academy of Sciences, 100 (14) pp.8062-8067; DOI: 10.1073/pnas.1231331100.

[17] Vogt, S. 2021. Landscaping to Attract Pollinators. Information on https://dyckarboretum.org/blog/.

[18] Information on http://landezine.com/index.php/2011/08/post-industrial-landscapearchitecture/?_cf_chl_jschl_tk

[19] Information on https://www.gardenvisit.com/gardens/duisburg_nord_landschaftspark

[20] Information on http://landezine.com/index.php/2011/08/post-industrial-landscape-architecture/?

[21] Information on https://archinect.com/news/article.

[22] Information on https://www.porturbanism.com/work/gateway-national-park/.

[23] Information on http://www.hargreaves.com/work/chattanooga-21st-century-waterfront-park/.

[24] Information on https://www.lampartners.com/portfolio/chattanooga-21 st-century-waterfront/.

[25] Information on http://www.hargreaves.com/work/chattanooga-21st-century-waterfront-park/. 
[26] 23461 Adopt 21st Century Waterfront Plan.pdf. Information on https://chattanooga.gov/citycouncil-files.pdf.

[27] Information on http://www.hargreaves.com/work/elizabeth-caruthers-park/.

[28] Information on https://www.portland.gov/parks/elizabeth-caruthers-park.

[39] Information on https://www.asla.org/portland/site.aspx?id=43610.

[30] Information on https://www.asla.org/portland/site.aspx?id=43610.

[31] Information on https://www.portland.gov/parks/elizabeth-caruthers-park.

[32] Information on http://www.sherwoodengineers.com/projects/tanggu-riverfront-park/.

[33] Information on http://www.hargreaves.com/work/haihe-river-ribbon-park/.

[34] Information on http://www.hargreaves.com/work/haihe-river-ribbon-park/. 